\title{
The diversity of fungi consortium isolated from polluted soil for degrading petroleum hydrocarbon
}

\author{
RIRYN NOVIANTY ${ }^{1, \vartheta}$, SARYONO ${ }^{1}$, AMIR AWALUDDIN ${ }^{1,}$ NOVA WAHYU PRATIWI ${ }^{2}$, ANNISA HIDAYAH ${ }^{1}$, \\ ERIWINA JULIANTARI ${ }^{3}$ \\ ${ }^{1}$ Department of Chemistry, Faculty of Mathematics and Natural Sciences, Universitas Riau. Jl. Subrantas Km. 12,5, Kampus Bina Widya Simpang Baru, \\ Tampan, Pekanbaru 28293, Riau, Indonesia. Tel.: +62-761-63273, `email: rirynnovianty@ @ecturer.unri.ac.id \\ ${ }^{2}$ Department of Biology, Faculty of Mathematics and Natural Sciences, Universitas Riau. Jl. Subrantas Km. 12,5, Kampus Bina Widya Simpang Baru, \\ Tampan, Pekanbaru 28293, Riau, Indonesia \\ ${ }^{3}$ Department of Biology, Faculty of Mathematics and Natural Sciences, Institut Pertanian Bogor. Jl. Meranti, Kampus IPB Dramaga, Bogor 16680, West
} Java, Indonesia

Manuscript received: 20 September 2021. Revision accepted: 26 October 2021.

\begin{abstract}
Novianty R, Saryono, Awaluddin A, Pratiwi NW, Hidayah A, Juliantari E. 2021. The diversity of fungi consortium isolated from polluted soil for degrading petroleum hydrocarbon. Biodiversitas 22: 5077-5084. One of the major problems in the petroleum industry nowadays is crude oil spills. Riau Province, Sumatra is one of the largest oil producers in Indonesia. Accidental releases of petroleum products are of particular concern to the environment. The process of drilling and refining petroleum generates a large amount of oil sludge. One of the effective technologies used in the waste degradation process is bioremediation using certain microorganisms. The prime objective of the current research was to evaluate the efficiency of fungi consortiums in crude oil degradation in Bumi Siak Pusako-Pertamina Hulu, Indonesia. There are three potential fungi isolates as petroleum hydrocarbon degradation agents with four consortium variations. The parameter values of Optical Density (OD), $\mathrm{pH}$, and diluted $\mathrm{CO}_{2}$ were measured on $0,4,8$, and 16 days. To evaluate the fungal biodegradation activity using Gas Chromatography-Mass Spectrometry (GC-MS). The result showed that consortium II (KF II) has the highest potential to degrade petroleum hydrocarbon (50.61\%). The visual GC-MS examination confirmed a decrease in the peak area for eight hydrocarbon compounds, indicating the efficiency of the fungi in the oil decomposition and dismantling of hydrocarbons. Our findings may provide new information on native fungal resources from chronically contaminated terrestrial environments, and will be useful for petroleum-contaminated bioremediation and other industrial applications.
\end{abstract}

Keywords: Biodegradation, crude oil, fungi consortiums, petroleum contaminants

\section{INTRODUCTION}

Riau Province, Sumatra, is one of the largest oil producers in Indonesia. The growth of the petroleum industry in Riau triggers environmental pollution. The pollution could be caused either by production or distribution activities (Grifoni et al. 2017). Activities of the petroleum industry (drilling, refining, production processes, and transport) generally produce waste oil and spill in land area. Waste and spills will be increased in line with increased activity in the field of the petroleum industry. Improper handling can cause environmental pollution and be dangerous for living beings and the environment (Darsa et al. 2014; Adeogun and Adekunle 2015; Taha et al. 2020).

Petroleum crude oil waste contains high molecular weighted aliphatic and aromatic hydrocarbons. These compounds in the environment will cause the death of living beings due to decreased oxygen levels, direct toxicity of hazardous substances from some hydrocarbons such as naphthalene, anthracene, and phenanthrene which is carcinogenic (Al-hawash et al. 2018). The level of toxicity of petroleum hydrocarbons can be acute or chronic. The effect of acute toxicity generally attacks the central nervous system. Chronic toxic properties can affect bone marrow cell damage and cause cancer (Khan et al. 2018).

One of the methods to overcome the environmental pollution caused by crude oil waste is using biological agents such as microorganisms that can degrade petroleum hydrocarbons ( $\mathrm{Xu}$ et al. 2018). The effort is known as bioremediation. Bioremediation is a waste or contaminated environment treatment technology by utilizing the local biota originating from the polluted environment.

Local biota is a petrophysics indigen microbe that can degrade the hydrocarbon component. The ability of petroleum degrading microbes can be enhanced by combining several isolates of microorganisms (consortium) (Titah et al. 2018). There are several benefits of microbes that degrade oil, such as the ability to adapt and thrive in their environment and the ability to degrade hydrocarbons (Kermani et al. 2015; Sari and Trihadiningrum 2019; Olawale et al. 2020).

The indigenous microorganisms, both bacteria (Novianty et al. 2020a) and fungi (Sari et al. 2019; Hamad 2021), have degraded hydrocarbon components. Naphthalene toxic compounds can also be degraded by bacteria (Novianty et al. 2020b) and fungi (Fitrida et al. 2020a). The addition of glucose co-substrate as a carbon source can also increase the biodegradability of naphthalene by bacteria (Smith et al. 2015) and fungi 
(Fitrida et al. 2020b). Fungi are particularly good candidates for remediation because they have extracellular enzymes that can metabolize hydrocarbons at the start of degradation and are capable of catabolizing recalcitrant hydrocarbons (Ramdass and Rampersad 2021). The ability of fungi to degrade hydrocarbons can also be increased by creating a fungi consortium isolated from polluted soil and reused to degrade hydrocarbons (Kermani et al. 2015; Briffa et al. 2020).

Biodegradation could be determined by many methods, including the Gas Chromatography technique which is used to determine the hydrocarbon degradation efficiency (Singh et al. 2015). GC-MS is used to identify all the compositions of petroleum hydrocarbons. These methods are highly selective, and compounds can be authenticated by analyzing their mass spectra and retention times (Alnuaimi et al. 2020). The prime objective of the current research was to evaluate the efficiency of fungi consortiums in crude oil degradation in Bumi Siak Pusako-Pertamina Hulu, Indonesia followed by the analysis of the biodegradation products using GC-MS.

\section{MATERIALS AND METHODS}

\section{Materials and instrumentation}

The isolate of microorganisms used in the study were FTM1 (Aspergillus sp.), FTM4 (Penicillium sp.), and FTM8 (Aspergillus sp.). The hydrocarbon-degrading strains of Aspergillus and Penicillium are isolated from soil (Spini et al 2018). Fungi consortium consisted of 1. KF1: isolate FTM1 and FTM4; 2. KF2: isolate FTM1 and FTM8; 3.KF3: isolate FTM4 and FTM8; 4. KF4: isolate FTM1, FTM4 and FTM8. Crude oil (5\%) from the mining site of Badan Operasi Bersama (BOB) PT Bumi Siak PusakoPertamina Hulu, Riau, Indonesia. The main apparatus used in this study were autoclave, rotary shaker with an agitation speed of $150 \mathrm{rpm}$, UV-VIS spectrophotometer with a wavelength of $600 \mathrm{~nm}$, and Gas Chromatography-Mass Spectrometry (GC-MS).

\section{Procedure}

\section{Isolation consortium technique}

The starter media for each fungal isolate (FTM1, FTM4 and FTM8) on Medium Potato Dextrose Broth (PDB) were incubated at room temperature in a rotary shaker with an agitation speed of $150 \mathrm{rpm}$ for 5-7 days. The inoculum was filtered to separate the fungal mycelia from the suspension using glass wool.

\section{Biodegradation effectiveness test against crude oil}

Biodegradation effectiveness test against crude oil used Bushnell Haas medium. The isolates were incubated for 16 days on a rotary shaker at $150 \mathrm{rpm}$ at room temperature. Then each isolate was inoculated into Bushnell Haas media according to the variation of the consortium. Each inoculum was monitored on days $0,4,8,12$, and 16 days (Vanishree et al. 2014) to measure the parameters of $\mathrm{pH}$, $\mathrm{OD}$, and levels of $\mathrm{CO}_{2}$. As a control, used Haas Bushnell medium with crude oil (without isolate fungi).
The ability of the fungal consortium to degrade crude oil hydrocarbons was monitored for 16 days through the parameters of Optical Density (OD), $\mathrm{pH}$, and dissolved Carbon Dioxide $\left(\mathrm{CO}_{2}\right)$. measured Optical Density (OD) on the mushroom suspension. using a UV-VIS spectrophotometer at a wavelength of $600 \mathrm{~nm}$. The determination of $\mathrm{pH}$ used a $\mathrm{pH}$ meter, and Estimated $\mathrm{CO}_{2}$ used $1 \mathrm{~mL}$ samples were taken and titrated with $0.1 \mathrm{M}$ $\mathrm{NaOH}$ and using phenolphthalein as an indicator. The formation of the pink color is considered as the endpoint.

The crude oil hydrocarbon degradation test by variations of the fungi consortium after 16 day incubation used the gravimetric method with $\mathrm{N}$-hexane solvent. After extraction, the solvent is evaporated, and petroleum weights are determined by weighing to obtain a constant weight. The percentage of petroleum biodegradation is calculated by using the formula:

$$
\% B=\frac{(B M o-B M n)}{B M o} \times 100
$$

Where: \% B: percent biodegradation; BMo: petroleum initial weight $(\mathrm{g})$; BMn: petroleum final weight $(\mathrm{g})$.

\section{Analysis of crude oil hydrocarbon components}

Hydrocarbon components of crude oil that were degraded by fungi consortium with the highest percentage were analyzed using the Gas Chromatography-Mass Spectrometry (GC-MS) Agilent Technology model 19091S-433. The conditions of the GC-MS equipment used are as follows: in the oven the initial temperature is $35^{\circ} \mathrm{C}$ and the maximum temperature is $325^{\circ} \mathrm{C}$. In the mobile phase, a split mode was used with initial temperature $250^{\circ} \mathrm{C}$, pressure $1.30 \mathrm{psi}$, split ratio $100: 1$, split flow 55.5 $\mathrm{mL} / \mathrm{min}$, total flow: $59.1 \mathrm{~mL} / \mathrm{min}$. The type of gas used is helium. The column used is Agilent model number 19091S-433 HP-5MS 5\% penyl methyl siloxane with a maximum temperature: $325^{\circ} \mathrm{C}$ with a length: $30.0 \mathrm{~m}$, diameter: $250.00 \mathrm{um}$, layer thickness $0.25 \mathrm{um}$. The injection volume is 0.20 microliters and the syringe size is 10.0 microliters.

\section{RESULTS AND DISCUSSION}

\section{Optical Density (OD) parameters during the degradation of crude oil}

Hydrocarbons Growth of microorganisms in liquid Bushnell Haas media by modification of $5 \% \mathrm{v} / \mathrm{v}$ crude oil was observed through Optical Density (OD) parameters in each consortium and control during incubation time of 0,4 , 8, 12, and 16 days. OD was measured using a UV-Vis spectrophotometer at a wavelength of $610 \mathrm{~nm}$ (Figure 1). It can be seen that there was an increase in the growth of fungal isolates on the 4th day of incubation, then fluctuated until the 16th day of incubation, except for KF2 which had an increased OD value. 


\section{pH parameters during the degradation of crude oil hydrocarbons}

The $\mathrm{pH}$ parameter is an important factor affecting the metabolic activity and growth of microorganisms. The fungi consortium during the degradation process work at $\mathrm{pH}$ 6.5-7. The $\mathrm{pH}$ parameter of fungi consortium is shown in the following Figure 2 that can be seen a decrease in the $\mathrm{pH}$ value of the fungal consortium on the 8th day of incubation. The decrease of $\mathrm{pH}$ in the medium during the incubation period indicates a chemical change of the hydrocarbon substrate caused by the enzymes of microorganisms and organic acid productions. The increase in $\mathrm{pH}$ that occurs during the incubation period is thought to be caused by the ability of microorganisms to carry out homeostasis to the acidity of the media.

\section{$\mathrm{CO}_{2}$ parameters during the degradation of crude oil hydrocarbons}

Biodegradation of crude oil hydrocarbons produces $\mathrm{CO}_{2}, \mathrm{H}_{2} \mathrm{O}$, and cell biomass. The $\mathrm{CO}_{2}$ contained in the liquid Bushnell Haas media was measured using the titration method. $\mathrm{CO}_{2}$ parameter in the variation of fungi consortium is shown in the following Figure 2. It can be seen that there was a fluctuation of $\mathrm{CO}_{2}$ from day 0 to day 16 of incubation. The active members of the microbial consortium can degrade pollutants under different environmental conditions. The increase in $\mathrm{CO}_{2}$ shows the activity of microorganisms in degrading crude oil hydrocarbons, which are increasing (Briffa et al. 2020). Most biodegradation reactions take place aerobically with the formation of $\mathrm{CO}_{2}$ gas because, in the breakdown of hydrocarbons, oxygen is needed to produce the oxygenase enzyme, which will produce $\mathrm{CO}_{2}$ (Titah et al. 2018). One of the factors causing the decrease in $\mathrm{CO}_{2}$ value during the degradation process is the effect of nutrient supplementation and microbial inoculation.

\section{Crude oil hydrocarbon degradation test uses the gravimetric method}

The crude oil hydrocarbon degradation test by variations of the fungi consortium used the gravimetric method. The KF2 fungi isolate consisted of two isolates of Aspergillus sp. was the most superior consortium in degrading oil hydrocarbons with $50.61 \%$ (Table 1). Aspergillus can inhibit the growth of mycelia in Penicillium fungi so that these two types of fungi do not work well together in the fungus consortium (Smith et al. 2015).

Natural microbial communities of KF2 located in different habitats have different physiological adaptations to degrade toxic compounds. Microbes will degrade crude oil hydrocarbons from simple bonding compounds to complex bonds. In general, the order of hydrocarbon degradation is n-alkanes, branched-chain alkanes, aromatic compounds, and cyclic bond alkanes (Kermani et al. 2015).

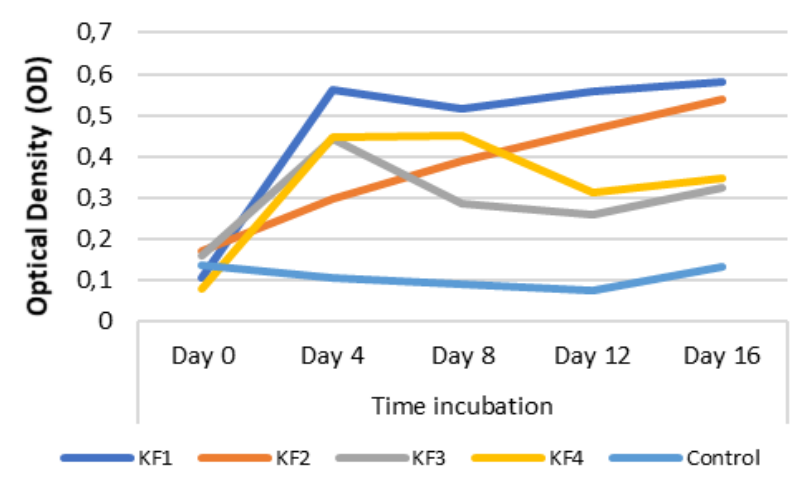

Figure 1. Optical Density (OD) of fungi consortium

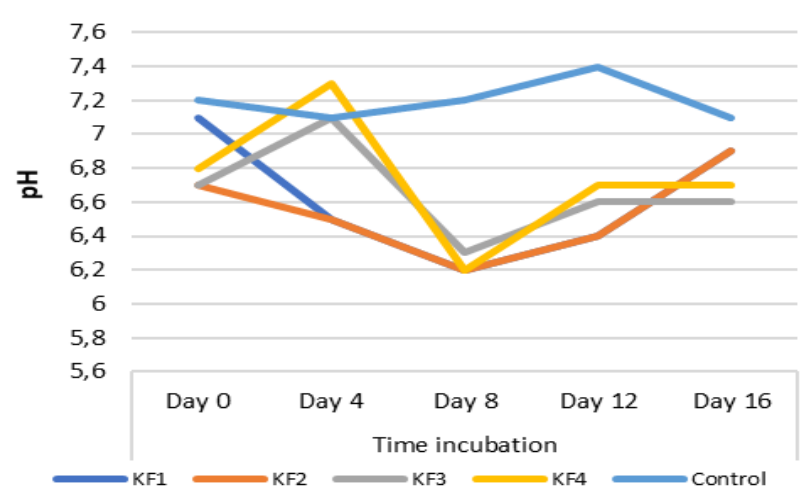

Figure 2. $\mathrm{pH}$ of fungi consortium

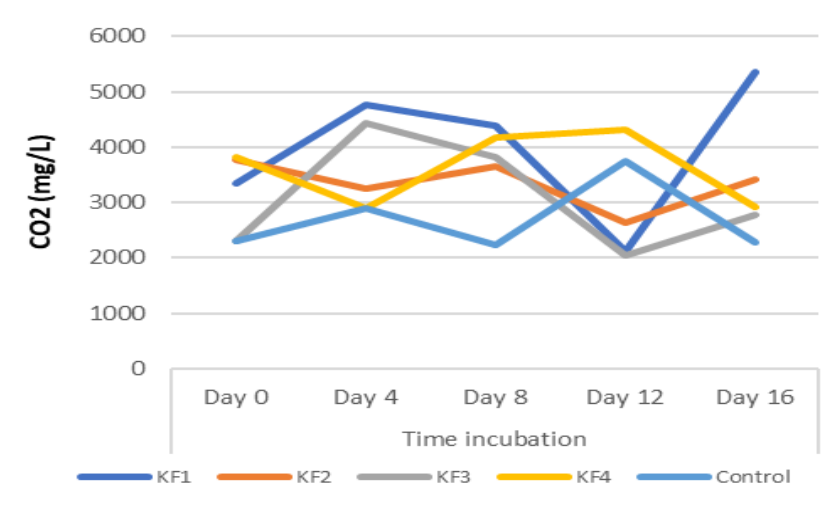

Figure 3. $\mathrm{CO}_{2}$ fungi consortium

Table 1. The constant weight of crude oil after degradation by fungi consortium

\begin{tabular}{lcc}
\hline Consortium & $\begin{array}{c}\text { Crude oil weight after } \\
\text { degradation }(\mathbf{g})\end{array}$ & $\begin{array}{c}\text { Percentage of } \\
\text { crude oil }\end{array}$ \\
\hline KF1 & 2.1333 & $43.94 \%$ \\
KF2 & 1.6928 & $50.61 \%$ \\
KF3 & 2.6768 & $35.72 \%$ \\
KF4 & 2.5661 & $37.40 \%$ \\
\hline
\end{tabular}




\section{Analysis of crude oil hydrocarbon components using GC-MS instrument}

Continuous developments in analytical instrumentation have brought the newly developed Orbitrap-based gas chromatography/mass spectrometry (GC/MS) instrument to the forefront for the analysis of complex mixtures such as crude oil. Hydrocarbon components of crude oil that were degraded by each fungi consortium with the highest percentage was KF2. KF2 isolate is the most superior consortium in degrading the dangers of crude oil so that the GC-MS analyze was carried out by comparing with the control isolates (Table 2). Chromatogram result of GC-MS crude oil on control is presented in Figure 4 and mass spectrum of crude oil compositions on control and KF2 in Figure 5.

Table 2 and Figure 4 show ten hydrocarbon compounds found in the control and only two compounds in KF2 which means KF2 could degrade 8 compounds. Figure 5 shows that the 9 compounds detected by GC-MS are nalkanes which have chain lengths from C-6 to C-31 and only one compound has an aromatic structure (Iron, tricarbonyl[N-(phenyl-2-pyridinylmethylene)benzylamine$\left.\mathrm{N}, \mathrm{N}^{\prime}\right](\mathrm{C} 21 \mathrm{H} 14 \mathrm{FeN} 2 \mathrm{O} 3)$. The aromatic compound was only present in the control and was degraded by KF2. Based on the mass spectrum of the aromatic compound in Figure 5, it can be seen that the base peak $\mathrm{m} / \mathrm{z}=57$ is an isotope of iron atoms, namely $57 \mathrm{Fe}$. The molecular ion peak $(\mathrm{M}+)$ is $\mathrm{m} / \mathrm{z}=282$ which indicates the number of carbon atoms in the compound is 21 (C21). Fragmentation characterized by peaks with a mass difference of 28 is the presence of a carbonyl group $(\mathrm{C}=\mathrm{O})$ at $\mathrm{m} / \mathrm{z} 85,71,57,43$. The fragmentation pattern at peaks with a mass difference of 16 is the presence of amine $\left(\mathrm{NH}_{2}\right)$ at $\mathrm{m} / \mathrm{z} 57,43,41,27$.

Table 2. Results of GC-MS analysis of the fungi consortium (KF2)

\begin{tabular}{|c|c|c|c|c|c|c|}
\hline Crude oil compositions & Control & RT & $\%$ area & KF2 & RT & $\%$ area \\
\hline Methylcyclopentane $\left(\mathrm{C}_{6} \mathrm{H}_{12}\right)$ & $\sqrt{ }$ & 1.594 & 7.99 & $\sqrt{ }$ & 1.696 & 2.24 \\
\hline Dodecane $\left(\mathrm{C}_{12} \mathrm{H}_{26}\right)$ & $\sqrt{ }$ & 7.708 & 3.07 & $\mathrm{x}$ & $\mathrm{X}$ & $\mathrm{x}$ \\
\hline Tridecane $\left(\mathrm{C}_{13} \mathrm{H}_{28}\right)$ & $\sqrt{ }$ & 9.389 & 4.93 & $\mathrm{x}$ & $\mathrm{x}$ & $\mathrm{x}$ \\
\hline Tetradecane $\left(\mathrm{C}_{14} \mathrm{H}_{30}\right)$ & $\sqrt{ }$ & 11.071 & 6.84 & $\mathrm{x}$ & $\mathrm{x}$ & $\mathrm{x}$ \\
\hline Pentadecane $\left(\mathrm{C}_{15} \mathrm{H}_{32}\right)$ & $\sqrt{ }$ & 12.753 & 8.82 & $\sqrt{ }$ & 15.232 & 5.45 \\
\hline $\begin{array}{l}\text { Iron. tricarbonyl[ } \mathrm{N} \text {-(phenyl-2-pyridinylmethylene) } \\
\text { benzenamine-N.N'] }\left(\mathrm{C}_{21} \mathrm{H}_{14} \mathrm{FeN}_{2} \mathrm{O}_{3}\right)\end{array}$ & $\sqrt{ }$ & 14.406 & 7.62 & $\mathrm{x}$ & $\mathrm{x}$ & $\mathrm{x}$ \\
\hline Nonadecane $\left(\mathrm{C}_{19} \mathrm{H}_{40}\right)$ & $\sqrt{ }$ & 16.059 & 4.21 & $\mathrm{x}$ & $\mathrm{x}$ & $\mathrm{x}$ \\
\hline Eicosane $\left(\mathrm{C}_{20} \mathrm{H}_{42}\right)$ & $\sqrt{ }$ & 17.712 & 8.28 & $\mathrm{x}$ & $\mathrm{x}$ & $\mathrm{x}$ \\
\hline Hentriacontane $\left(\mathrm{C}_{31} \mathrm{H}_{64}\right)$ & $\sqrt{ }$ & 21.525 & 6.80 & $\mathrm{x}$ & $\mathrm{x}$ & $\mathrm{x}$ \\
\hline Pentacosane $\left(\mathrm{C}_{25} \mathrm{H}_{52}\right)$ & $\sqrt{ }$ & 23.648 & 6.15 & $\mathrm{x}$ & $\mathrm{x}$ & $\mathrm{x}$ \\
\hline
\end{tabular}

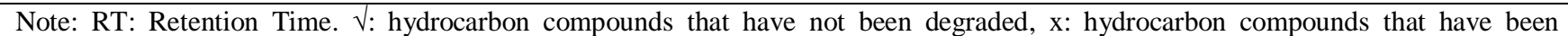
degraded

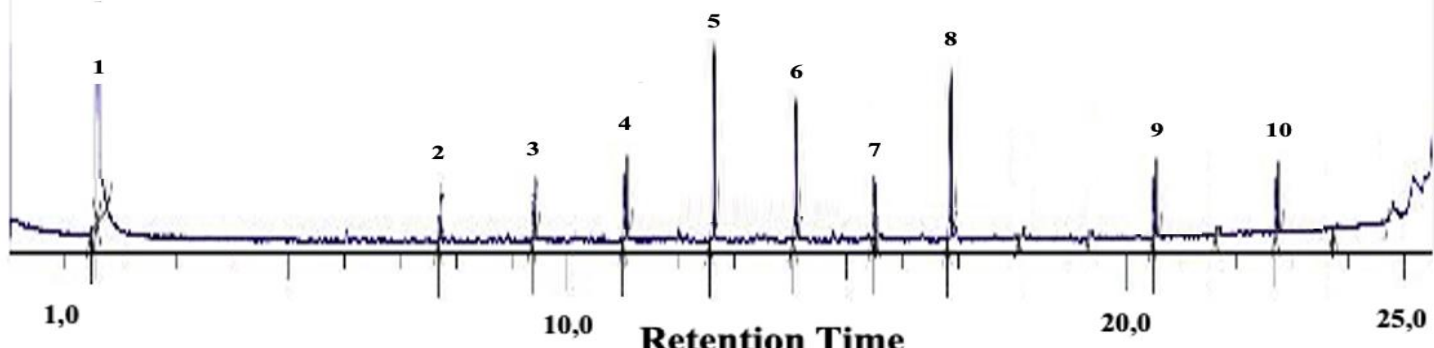

A

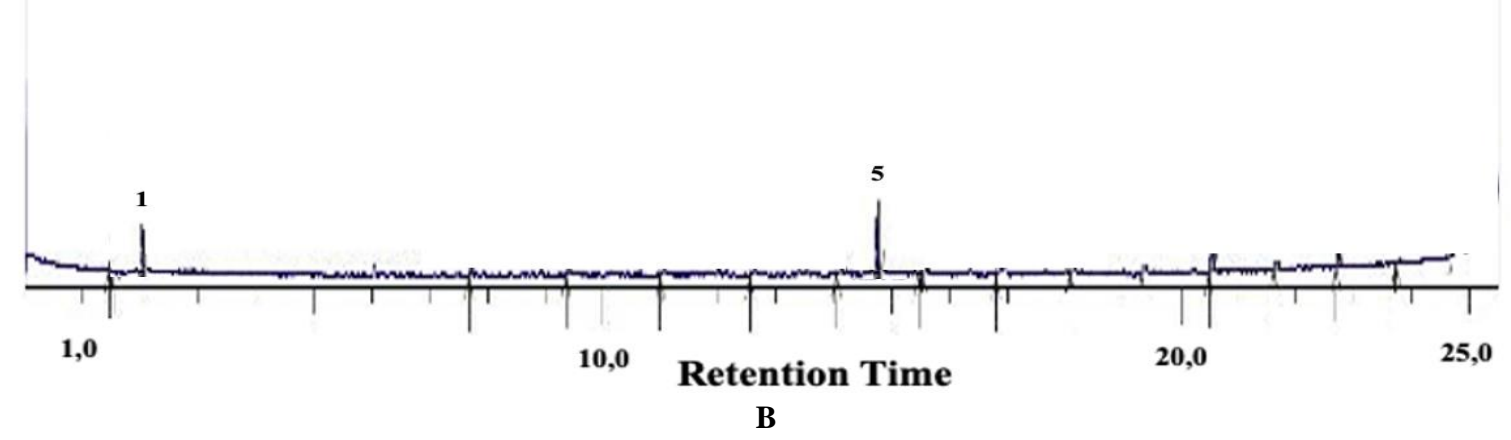

Figure 4. (A) Chromatogram of GC-MS crude oil on control and (B) KF2 
SI:95 Formula:C12 H26 CAS:112-40-3 MolWeight:170 Rethdes:0

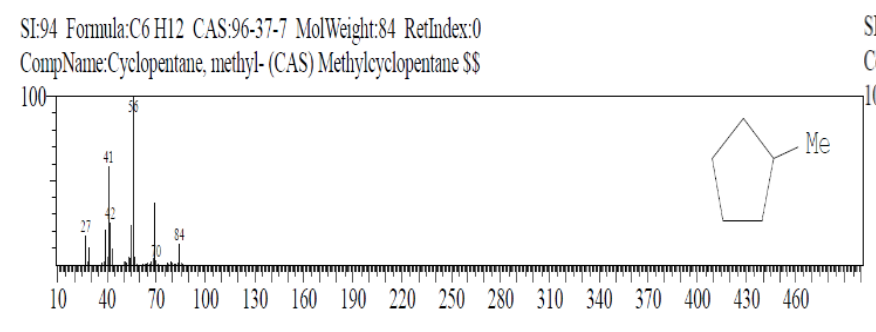

CompVame:Dodecane (CAS) n-Dodecane SS Ba 51-090453 SS Adakane 12 SS Isododecane SS CH3(CH2) 10CH3 SS Bit

Compame.Cyclopentane mathyl-(CAS) MethlcyclonentonesS

S:96 Fomulala:C13 H28 CAS:629-50-5 MoliWeight:184 Rethder:0

CompVame:Tridecane (CAS) n-Tridecane SS Tridecane, n- - S

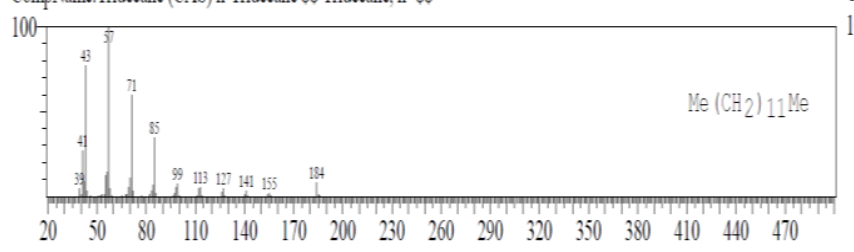

SI:05 Formula:Cl8 H38 CAS:3892-00-0 MolWeight2254 Rethndex:0

Complame:PENTADECANE, 2,6,10-TRIETHYL-S\$ NOR-PRISTAN SS

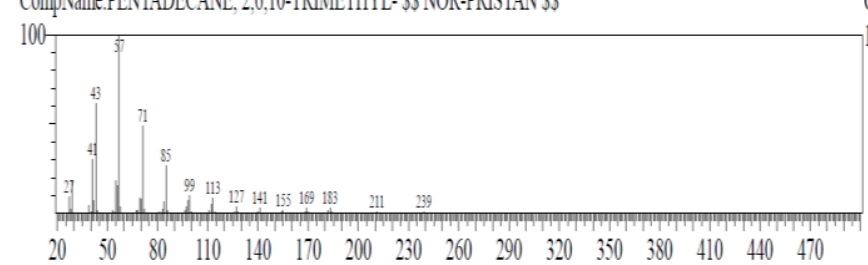

SL:97 Fomulala:C20 H42 CAS:112-95-8 MolWeight:282 Rethder:0

Complame:Eicosane (CAS) n-Eicosane SS

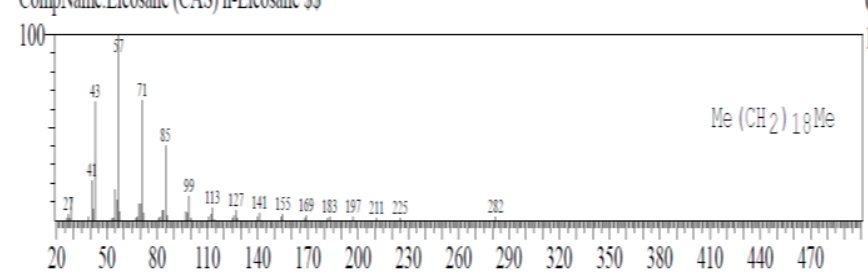

SL:97 Formula:C21 H14FE N2 03 CAS:74764-11-7 MolWeight:398 Rethnde:0

Complame:Iron, tricarbouyl[N-(phenyl-2-pyridinylmethylene) benzenamine-N,N]- S\$ RON, TRCARBONYL[N-(PHE

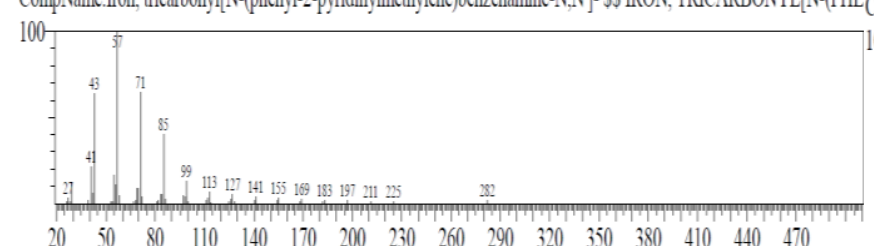

SL:96 Formula:C25 H52 CAS:629-99-2 MolWeight:352 Rethdex:0

CompName:Pentadecane, 2,610,14-tetramethyl- (CAS) Pristane \$S PRISTANE (FELD ION) \$ 2,6,10,14-Tetramethylp

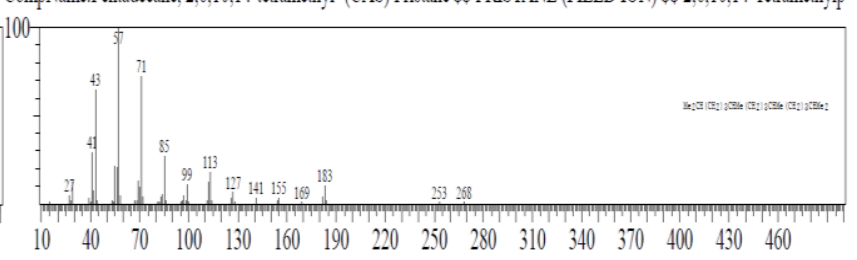

SL:96 Formula:C31 H64 CAS:630-04-6 MollWeight:437 Rethder:0

CompName:Hentriacontane (CAS) Untriacontane SS n-HentriacontaneSS
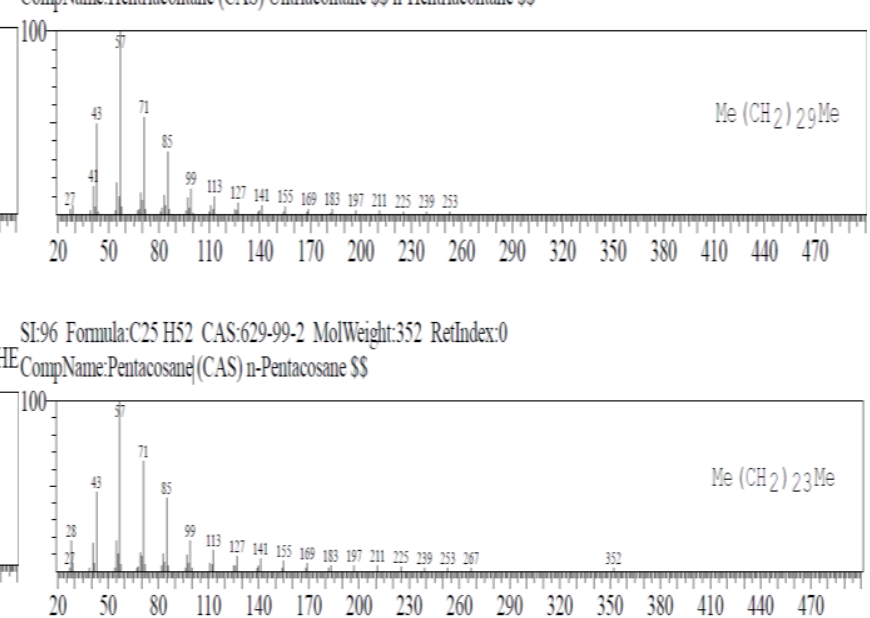

Figure 5. Mass spectrum of crude oil compositions on control and KF2

\section{Discussion}

The negative impact of crude oil hydrocarbon spills on a polluted environment will cause by soil and water pollution. Microorganisms that can degrade hydrocarbons are called hydrocarbonoclastic microorganisms. Biodegradation of complex hydrocarbons usually requires the cooperation of more than one species. This microorganism will degrade by cutting the hydrocarbon chain to simpler by involving various degradative enzymes that are very specific (Sharma et al. 2013; Parthipan et al. 2017; Karaghool et al. 2021). The rate of degradation of each fungus might be dependent on the type of enzyme involved and the number of enzymes secreted (Cao et al. 2020). Indigenous fungi become highly adapted to survival in hydrocarbon-contaminated terrestrial environments through selective enrichment and genetic modifications that enable them to catabolize xenobiotic chemicals (Marchand et al. 2017; Ramdass and Rampersad 2021). In this study, the diversity of indigenous fungi to degrade petroleum hydrocarbons isolated from the mining site of Badan Operasi Bersama (BOB) PT Bumi Siak Pusako-Pertamina Hulu, Riau, Indonesia.

The growth of microorganisms inoculated on the liquid Bushnell Haas medium was indicated by an increase in the 
turbidity of the solution. An increased OD value indicates that the growth of fungi in the liquid Bushnell Haas medium which crude oil has been added as a carbon source. An increased OD value in the early incubation period indicates that the microbes used hydrocarbons as a substrate for growth. Through the release of extracellular enzymes and acids that can break down hydrocarbon molecules by cutting long chains of hydrogen and carbon into simple forms that can be absorbed for nutrition and microbial growth. The OD value has decreased, due to the reduced availability of nutrients and the suspected release of toxic substances into the media resulting from the hydrocarbon degradation process (Adeogun and Adekunle 2015). Only the KF2 consortium continued to increase from day 0 to day 16 while the other consortium has decreased. This happens because this consortium was still in the Log (exponential) phase while the other fungi consortium has reached the death phase. In the exponential phase, microbes divide rapidly and constantly so that growth increases. The speed of growth in this phase is strongly influenced by the $\mathrm{pH}$ and nutrient content of the growth media (Surono and Narisawa 2017).

The optimum $\mathrm{pH}$ parameter for hydrocarbon biodegradation is around $\mathrm{pH}$ 6-8 (Chen et al. 2017; Grifoni et al. 2017). The utilization of crude oil as the sole source of carbon and energy affects microbiological metabolic activity and results in the growth of microorganisms with the simultaneous production of carboxylic acids (Fauzi et al. 2016; Grifoni et al. 2017). Murali et al. (2017) stated that the production of carboxylic acids during the degradation process causes changes in $\mathrm{pH}$ which also indicates that there is a degradation of contaminant compounds in crude oil, one of which is the degradation of alkane compounds. Alkanes are the largest class of chemical compounds that make up crude oil. These compounds are classified as long-chain compounds that are generally degraded by microorganisms. The $\mathrm{pH}$ value of the fungi consortium fluctuated during the degradation process, this indicates that there is an activity of microorganisms in degrading hydrocarbon compounds. The decrease in the $\mathrm{pH}$ value of the media by microorganisms will produce products in the form of organic acids. This decrease indicates that there are carboxylic acids that increase with increasing incubation time (Lund et al. 2020).

The release of $\mathrm{CO}_{2}$ during crude oil degradation can be used as an indicator of microorganism activity in the media. an increase in $\mathrm{CO}_{2}$ indicates an increasing activity of microorganisms in degrading crude oil hydrocarbons. Most of the biodegradation reactions take place aerobically with the indicated formation of $\mathrm{CO}_{2}$ gas because in the breakdown of hydrocarbons oxygen is needed to produce oxygenase enzymes which will produce $\mathrm{CO}_{2}$ (Rosmawati and Rijal 2020). One of the factors causing the decrease in $\mathrm{CO}_{2}$ value during the degradation process is the effect of decreasing nutrient availability in the media (Darsa et al. 2014).

A microbial consortium using two different microbes, each specific for a particular activity, is a newer approach used to recover environmental damage. Isolate KF2 was more potent than other isolates because of its enzyme production ability so that it can be used to remove hydrocarbon pollutants from the contaminated environment. KF2 is a consortium of isolates from the same genus, namely FTM1 (Aspergillus sp.) and FTM8 (Aspergillus sp.) so that the adaptation of isolates to the environment (media) will be faster. Katz and Everett (2016) stated that one of the factors that influence the degradation process of crude oil hydrocarbons is the ability of isolates to adapt more quickly to their environment. According to $\mathrm{Wu}$ et al. (2020) that isolates belonging to the same genus in the degradation process have a greater synergistic effect so that the effectiveness of degradation will also be increased. Fungi converted petroleum into simpler forms or products that can be absorbed for growth and nutrition.

The hydrocarbon degradation activity of crude oil is increasing, which is indicated by the increasing growth of microorganisms as measured by the value of Optical Density (OD), the production of carboxylic acid resulting in an increasingly acidic $\mathrm{pH}$ of the media, and the $\mathrm{CO}_{2}$ levels. The value of Optical Density (OD) during the degradation process indicates that the growth of microorganisms is maximum, the highest $\mathrm{pH}$ value indicates the maximum biodegradation rate and the highest $\mathrm{CO}_{2}$ value indicates maximum microbial activity. The results have shown that KF2 consortia demonstrated positive synergistic effects due to the different metabolic pathways employed by the individual microbial species. These results are in accordance with the finding obtained by Moneke and Nwangwu (2011) in terms of increasing the amount of oxygen, $\mathrm{pH}, \mathrm{CO}_{2}$ during hydrocarbon degradation, by Fanny et al. (2018) in terms of $\mathrm{pH}$ and degradation percentage of hydrocarbon and by (Ma et al. 2021) in terms of microbial consortium showed a highly efficient oil-degrading capacity and has significant application prospects in oil pollution bioremediation.

Mixed populations (co-culture or consortia) can perform functions that are difficult or even impossible for individual strains or species and those which require multiple steps (Brenner et al. 2008). Living together may provide robustness to environmental fluctuations, stability for the members, ability to share metabolites and weather periods of nutrient limitations, and resistance to invasion by other species. On the other hand, a variety of microbes within a consortium contain a more diverse set of metabolic pathways and a wider range of enzymes, expanding the metabolic range of hydrocarbon degradation. The synergistic effect of a microbial consortium enhances the oil-degradation ability compared to a single oil degrader (Santisi et al. 2015)

A critical requirement for microbial consortia is communication between populations. Communication can be implemented using small diffusible molecules such as metabolites compounds or using secreted enzymes. The degradation process for 16 days incubation mostly degraded the simplest compound of hydrocarbons, namely n-alkanes. Microorganisms capable of producing enzymes that function as biocatalysts of enzymatic reactions biodegradation of aliphatic compounds, by alkane mannosidase enzymes, alcohol dehydrogenase, and 
formaldehyde dehydrogenase (Adlan et al. 2020). Aerobic degradation of alkanes usually begins with the oxidation of methyl groups to produce primary alcohols. This product is further oxidized by alcohol dehydrogenase and aldehyde dehydrogenase to form aldehydes which are further oxidized to carboxylic acids (Koshlaf and Ball 2017). Carboxylic acid will be converted by acyl CoA to form acetyl $\mathrm{CoA}$ through an oxidation reaction. Acetyl CoA is converted to $\mathrm{CO}_{2}$ through the Krebs cycle.

The degradation of aromatic compounds by microbes begins through a catabolism process starting with the oxidation step of one of the aromatic rings. This reaction is catalyzed by the enzyme hydroxylase of aromatic hydrocarbons and forms cis-dihydrodiols. Dihydrodiol is then oxidized by the enzyme dehydrogenase reaction to produce PAH derivatives. Dihydroxylase intermediates may be formed via the intradiol (ortho) cleavage pathway or via the intradiol ring (meta) cleavage pathway, with catechol formation and further metabolization to carbon dioxide and water via the TCA cycle (Kreb cycle) (Koshlaf and Ball 2017). Our findings in this research may provide new information on native fungal resources from chronically contaminated terrestrial environments, and will be useful for petroleum contamination bioremediation and other industrial applications.

\section{ACKNOWLEDGEMENTS}

All authors would like to thank the Laboratory and Research group for the technical help and deep discussion on these topics. We acknowledge our institution "University of Riau", Indonesia for the various research facilities and provided funding for this research by Budget Implementation List (DIPA) with Contract Agreement Number: 796/UN.19.5.1.3/PP/2017.

\section{REFERENCES}

Adeogun OO, Adekunle AA. 2015. Biodegradation of petroleum products using phylloplane fungi isolated from selected plants. J Sci Res Dev 15: 45-43.

Adlan NA, Sabri A, Masomian M, Ali MSM. 2020. Microbial biodegradation of paraffin wax in Malaysia crude oil mediated by degradative enzyme. Front Microbiol 11: 1-15. DOI: 10.3389/fmicb.2020.565608.

Alnuaimi MT, Taher TA, Aljanabi ZZ, Adel MM. 2020. High-resolution GC/MS study of biodegradation of crude oil by Bacillus megaterium. Res Crops 21: 650-657. DOI: 10.31830/2348-7542.2020.101.

Al-Hawash AB, Dragh MA, Li S. 2018. Principles of microbial degradation of petroleum hydrocarbons in the environment. Egypt J Aquat Res 44: 71-76. DOI: 10.1016/j.ejar.2018.06.001

Briffa J, Sinagra E, Blundell R. 2020. Heavy metal pollution in the environment and their toxicological effectson humans. Heliyon 6: 1 26. DOI: 10.1016/j.heliyon.2020.e04691.

Brenner K, You L, Arnold FH. 2008. Engineering microbial consortia: a new frontier in synthetic biology. Trends Biotechnol 26: 483-489. DOI: $10.1016 /$ j.tibtech.2008.05.004.

Cao H, Wang C, Liu H, Jia W, Sun H. 2020. Enzyme activities during Benzo(a) pyrene degradation by the fungus Lasiodiplodia theobromae isolated from polluted soil. Science 10: 1-13. DOI: 10.1038/s41598020-57692-6.

Chen Q, Li J, Sun H, Bao M. 2017. Study on the biodegradation of crude oil by free and immobilized bacterial consortium in marine environment. Plos One 12: e0174445. DOI: 10.1371/journal.pone.0174445.

Darsa KV, Thatheyus J, Ramya D. 2014. Biodegradation of petroleum compound using the bacterium Bacillus subtilis. Sci Intl J 10 (2): 2025. DOI: $10.17311 /$ sciintl.2014.20.25.

Fanny ND, Linda TM, Martina A. 2018. Ability of single and consortium Actinomycetes riau on degradation of crude Oil. Bio-site 4: 53-60.

Fauzi M, Suryatmana P. 2016. Bioremediation of crude oil waste contaminated soil using petrophilic consortium and Azotobacter sp. J Degrade Mining Land Manag 3 (2): 521-526.

Fitrida A, Apriyana K, Astuti R, Novianty R. 2020a. Biodegradation of environmental pollutant naphthalene toxic compounds using indigenous fungi isolates in Riau Province. Jurnal Ipteks Terapan 13: 165-174. DOI: 10.22216/jit.2019.v13i3.4236. [Indonesian]

Fitrida A, Novianty R, Saryono, Awaluddin, A, Pratiwi NW. 2020 b. Optimization of the growth of isolates of indigenous Penicillium sp. LBKURCC153 naphthalene degrading using glucose as cosubstrate in minimal medium. Jurnal Inovasi Pendidikan dan Sains 1 (1): 20-25. DOI: 10.51673/jips.v1i1.229. [Indonesian]

Grifoni M, Petruzzelli G, Barbafieri M, Rosellini I, Pedron F. 2017. Soil quality rotection at heavy metal contaminated manufactured gas plant sites: role of biological remediation. In: Enhancing Cleanup of Environmental Pollutants (eds.). Naser AA, Gill SS, Tuteja N. Springer, Cham. DOI: 10.1007/978-3-319-55426-6_11.

Hamad AA. 2021. Petroleum hydrocarbon bioremediation using native fungal isolates and consortia. Sci World J 2021: 1-13. DOI: $10.1155 / 2021 / 6641533$.

Karaghool HAKH. 2021. Biodecolorization of methylene blue using Aspergillus consortium. Earth Environ Sci 779: 1-10. DOI: 10.1088/1755-1315/779/1/012111.

Katz BJ, Everett MA. 2016. An overview of pre-devonian petroleum systems unique characteristics and elevated risks. Mar Petroleum Geol 73 (2): 492-516. DOI: 10.1016/j.marpetgeo.2016.03.019.

Kermani N, Ghasemi A, Khosravan M, Shakibaie M. 2015. Cadmium bioremediation by metal-resistant mutated bacteria isolated from active sludge of industrial effluent. J Environ Health Sci Eng 7: 279285.

Koshlaf E, Ball AS. 2017. Soil bioremediation approaches for petroleum hydrocarbon polluted environments. Microbiology 3 (1): 25-49. DOI: 10.3934/microbiol.2017.1.25.

Khan MAI, Biswas B, Smith E, Naidu R, Megharaj M. 2018. Toxicity assessment of fresh and weathered petroleum hydrocarbons in contaminated soil: a review. Chemosphere 2018: 1-54. DOI: 10.1016/j.chemosphere.2018.08.094.

Lund PA, Biase DD, Liran O, Scheler O, Mira NP, Cateciglu Z, Fernandez EN, Cid SB, Hall R, Sauer M, O’Byerne C. 2020. Understanding how microorganism respond to acid $\mathrm{pH}$ is central to their control and successful exploitation. Front Microbiol 11: 1-8. DOI: 10.3389/fmicb.2020.556140.

Ma M, Zheng L, Yin X, Gao W, Han B, Li Q, Zhu A, Chen H, Yang H. 2021. Reconstruction and evaluation of oil-degrading consortia isolated from sediments of hydrothermal vents in the South Mid-Atlantic Ridge. Nature 11: 1456. DOI: 10.1038/s41598-02180991-5.

Marchand C, St-Arnaud M, Hogland W, Bell TH, Hijri M. 2017. Petroleum biodegradation capacity of bacteria and fungi isolated from petroleum-contaminated soil. Intl Biodeterior Biodegrad 116: 48-57. DOI: $10.1016 /$ j.ibiod.2016.09.030.

Moneke A, Nwangwu C. 2011. Studies on the bioutilization of some petroleum hydrocarbons by single and mixed cultures of some bacterial species. Afr J Microbiol Res 5 (12): 1457-1466. DOI: 10.5897/AJMR10.839.

Murali N, Srinivas K, Ahring BK. 2017. Biochemical production and separation of carboxylic acids for biorefinery applications. Fermentation 3: 1-25. DOI: 10.3390/fermentation3020022.

Novianty R, Awaluddin A, Pratiwi NW. 2020a. Indigenous bacteria degrading petroleum hydrocarbons in Siak Regency, Riau Province. J Teknik Kimia USU 1: 34-40. [Indonesian]

Novianty R, Antika B, Saryono S, Awaluddin A, Pratiwi NW. 2020b. The potential of three isolates of indigenous bacteria from Siak Regency, Riau Province in degrading naphthalene. Jurnal Kimia 14: 94-100. DOI: 10.24843/JCHEM.2020.v14.i01.p16. [Indonesian]

Olawale S, Obayomi KS, Dahunsi SO, Folarin O, Cameselle C. 2020. Bioremediation of artificially contaminated soil with petroleum using animal waste: cow and poultry drug. Cogent Eng 7 (1): 1721409. DOI: $10.1080 / 23311916.2020 .1721409$. 
Parthipan P, Preetham E, Machuca LL, Rahman PKSM, Murugan K, Rajasekar A. 2017. Biosurfacant and degradatice enzymes mediated crude oil degradation by bacterium Bacillus subtilis A1. Front Microbiol 8 (193): 1-14. DOI: 10.3389/fmicb.2017.00193.

Ramdass AC, Rampersad SN. 2021. Diversity and oil degradation potential of culturable microbes isolated from chronically contaminated soils in Trinidad. Microorganism 9: 1-16. DOI: 10.3390/microorganisms9061167.

Rosmawati T, Rijal M. 2020. Isolation and activity test of hydrocarbon degrading mold from the petroleum waste of PT Ollop Bula in west seram district. Poll Res 39: 1-13.

Santisi S, Capello S, Catalfamo M, Marcini G, Hassanshahian M, Genovese L, Giuliano L, Yakimov MM. 2015. Biodegradation of crude oil by individual bacterial strains and a mixed bacterial consortium. Braz J Microbiol 46: 377-387. DOI: 10.1590/S1517838246120131276.

Sari EM, Novianty R, Awaluddin A, Saryono. 2019. Effectiveness of crude oil degrading fungi isolated from petroleum hydrocarbon contaminated soil in Siak, Riau. J Acta Biochimica Indonesiana 2: 15 22. DOI: 10.32889 /actabioina.v2i1.35.

Sari GL, Trihadiningrum Y. 2019. Bioremediation of petroleum hydrocarbons in crude oil contaminated soil from wonocolo public oilfields using aerobic composting with yard waste and rumen residue amendments. J Sustain Dev Energy Water Environ Syst 7: 482-492. DOI: $10.13044 /$ j.sdewes.d7.0262.

Sharma S, Singh A, Mathur NM, Verma A. 2013. Development of fungal consortium for biodeclorization of textile waste effluents: a review. Intl J Chem Sci 11: 891-910.

Smith K, Rajedran R, Kerr S, Lappin DF, Mackey WG, Williams C, Ramage G. 2015. Aspergillus fumingatus enhances elastase produvtion in Pseudomonas aeruginosa co-culturs. Med Mycol J 53: 645-655. DOI: 10.1093/mmy/myv048.
Spini G, Spina F, Poli A, Blieux AL, Regnier T, Gramellini C, Varese GC, Puglisi E. 2018. Molecular and microbiological insights on the enrichment procedures for the isolation of petroleum degrading bacteria and fungi. Front Microbiol 9: 25-43. DOI; 10.3389/fmicb.2018.02543.

Surono, Narisawa K. 2017. The dark septate endophytic fungus Phialocephala fortinii is a potential decomposer of soil organic compounds and a promoter of Asparagus officinalis growth. Fungal Ecol 28: 1-10. DOI: 10.1016/j.funeco.2017.04.001

Taha H, Shivanand P, Khoo DH, Mohammad YH, Matussin NBA, Metali F. 2020. Identification of culturable petroleum-degrading bacteria and fungi from petroleum-contaminated sites in Brunei Darussalam. J Environ Sci Health Part A 55 (13): 1542-1547. DOI: 10.1080/10934529.2020.1826238

Titah HS, Pratinko H, Moesriati A, Imron MF, Putera RI. 2018. Isolation and screening of diesel degrading bacteria from ship dismantling facility at Tanjungjati, Madura, Indonesia. J Eng Technol Sci 50: 99109. DOI: $10.5614 /$ j.eng.technol.sci.2018.50.1.7.

Vanishree M, Thatheyus AJ, Ramya D. 2014. Biodegradation of petrol using the fungus Penicillium sp. Ann Res Rev Biol 914-923. DOI: 10.17311/sciintl.2014.26.31

Wu XL, Gu YC, Wu XY, Zhou XY, Zhou H, Amanze C, Shen L, Zeng WM. 2020. Construction of a tetracycline degrading bacterial consortium and its application evaluation in laboratory-scale soil remediation. Microorganisms 8 (2): 292. DOI: 10.3390/microorganisms8020292

Xu X, Liu W, Tian S, Wang W, Qi Q, Jiang P, Gao X, Li F, Li H, Yu H. 2018. Petroleum hydrocarbon-degrading bacteria for the remediation of oil pollution under aerobic conditions: a perspective analysis. Front Microbiol 9: 1-11. DOI: 10.3389/fmicb.2018.02885. 